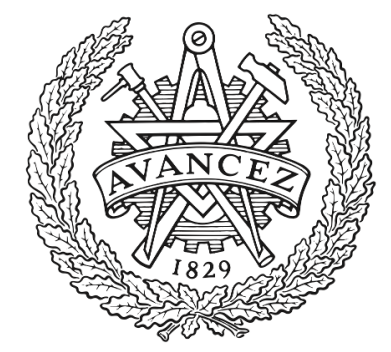

CHALMERS

UNIVERSITY OF TECHNOLOGY

\title{
Analysis of the mechanical impedance of bone-anchored hearing aids
}

Downloaded from: https://research.chalmers.se, 2023-04-26 14:53 UTC

Citation for the original published paper (version of record):

Tjellström, A., Håkansson, B., Lindström, J. et al (2018). Analysis of the mechanical impedance of bone-anchored hearing aids. Acta Oto-Laryngologica, 138(3): 288-296.

http://dx.doi.org/10.1080/00016489.2018.1438157

N.B. When citing this work, cite the original published paper. 


\section{Tjellström A et al. - Analysis of the mechanical impedance of bone-anchored hearing aids. Acta Oto-Laryngol 1980; 89: 85-92}

\section{Introduction}

In the 1960s, Professor Per-Ingvar Brånemark at Göteborg started his pioneering work on the unique properties of titanium in relation to bone and soft tissue, osseointegration. Following the early development of titanium implants for dental rehabilitation the next step concerned the idea of using a bone-anchored titanium implant requiring skin penetration, with which to attach the hearing aid.

The present paper is the first in a series of presentations implying an inter-disciplinary development program for boneanchored hearing aids. The study described and examined the mechanical system used to gain osseointegrated entry into the skull. The input impedance into the head in the frequency range of 250 to $8000 \mathrm{~Hz}$, both with and without skin penetration, was measured in 8 patients. The observations were of the utmost significance for further development of bone-anchored hearing aids, which nowadays are such useful tools for the rehabilitation of many hearing disabled individuals.

Sten Hellström Chairman, The Acta Oto-Laryngologica Foundation 
Acta Otolaryngol 89: 85-92, 1980

\title{
ANALYSIS OF THE MECHANICAL IMPEDANCE OF BONE-ANCHORED HEARING AIDS
}

\author{
A. Tjellström, ${ }^{1}$ B. Håkansson, ${ }^{2}$ J. Lindström, ${ }^{1}$ P.-I. Brånemark, ${ }^{3}$ \\ O. Hallén, ${ }^{1}$ U. Rosenhall ${ }^{4}$ and A. Leijon ${ }^{4}$

\begin{abstract}
From 'ENT-Department, Sahlgren Hospital, University of Göteborg, Göteborg, ${ }^{2}$ Laboratory of' Medical Electronics. Department of Applied Electronics, Chalmers University of Technology, Göteborg, ${ }^{3}$ Institute for Applied Biotechnology, Mölndal, and ${ }^{4}$ Department of Audiology, Sahlgren Hospital, University of Göteborg.
\end{abstract} \\ Göteborg, Sweden
}

(Received April 2, 1979)

\begin{abstract}
Some patients who need hearing aids are unable to use an apparatus which transmits the sound via the external ear canal and have to use a bone conduction hearing aid. The bone vibration transducer of this aid is applied to the skin över the mastoid process and the sound is transmitted via the soft tissue and bone to the cochlea. The pressure needed to apply the transducer often gives the patient discomfort and the damping effect of the soft tissue gives poor quality of the sound transmitted. Advances in the ability to permanently implant foreign material in the body and perform permanent skin penetration has made it possible to develop a bone-anchored hearing aid. Fourteen patients have been equipped with such hearing aids. To be able to give these patients the best hearing aid, a new transducer has to be constructed to match the new situation. The impedance of the boneanchored titaniumscrew/skull has been studied and the resistance and reactance of the mechanical impedance have been measured. The influence of a damping soft tissue layer over the bone has been analyzed. The difference between the impedance of the skull and the impedance of the soft tissue + skull was in the order of 10 to $25 \mathrm{~dB}$ depending on the frequency.
\end{abstract}

For various reasons some patients who need hearing aids cannot use an apparatus in which the sound is transmitted via a plastic ear mould in the external auditory canal, but require a bone conduction hearing aid instead. This means that the sound is transmitted to a bone conduction receiver applied to the skin over the mastoid process by means of a steel spring over the head, via soft tissue and bone into the cochlea. One reason why the patients must use such a hearing aid can be a chronic ear condition and that the ear starts to discharge as soon as the auditory canal is blocked by an ear mould. Other reasons are extreme transmis- sion impairments such as gross malformation of the ear canal and the middle ear and also extensive otosclerosis.

Patients with bone conduction hearing aids often complain about the pressure with which the hearing aid must be applied. This pressure is so great that it causes pain and one often sees reddening and irritated skin areas which indicate where the hearing aid has compressed the skin. The position of the apparatus must often be adjusted so that the patient can get the best hearing. This may be due to the roughness and convex nature of the bone surface under the skin which also hinders an exact and stable position of the hearing aid. Many patients complain about the poor sound quality which characterizes this type of hearing aid. Furhter, the steel spring over the head for holding the hearing aid in position can give esthetic problems for thin-haired men as well

This paper is the first in a series of presentations concerning an inter-disciplinary development program on bone-anchored hearing aids. The work is done in close cooperation between the Department of Otolaryngology, University of Göteborg (Head Prof. Olle Hallén), The Institute for Applied Biotechnology, Mönldal (Head Prof. P.-I. Brånemark), The Department of Audiology, University of Göteborg (Head Prof. G. Lidén) and the Laboratory of Medical Electronics, Department of Applied Electronics, Chalmers University of Technology, Göteborg (Head Prof. R. Magnussion).

This study was supported by grants from Stiftelsen Tysta Skolan, Stockholm, The Swedish Medical Research Council, project No. B 79-17X-05436-01 and The Göteborg Medical Society, Göteborg. 


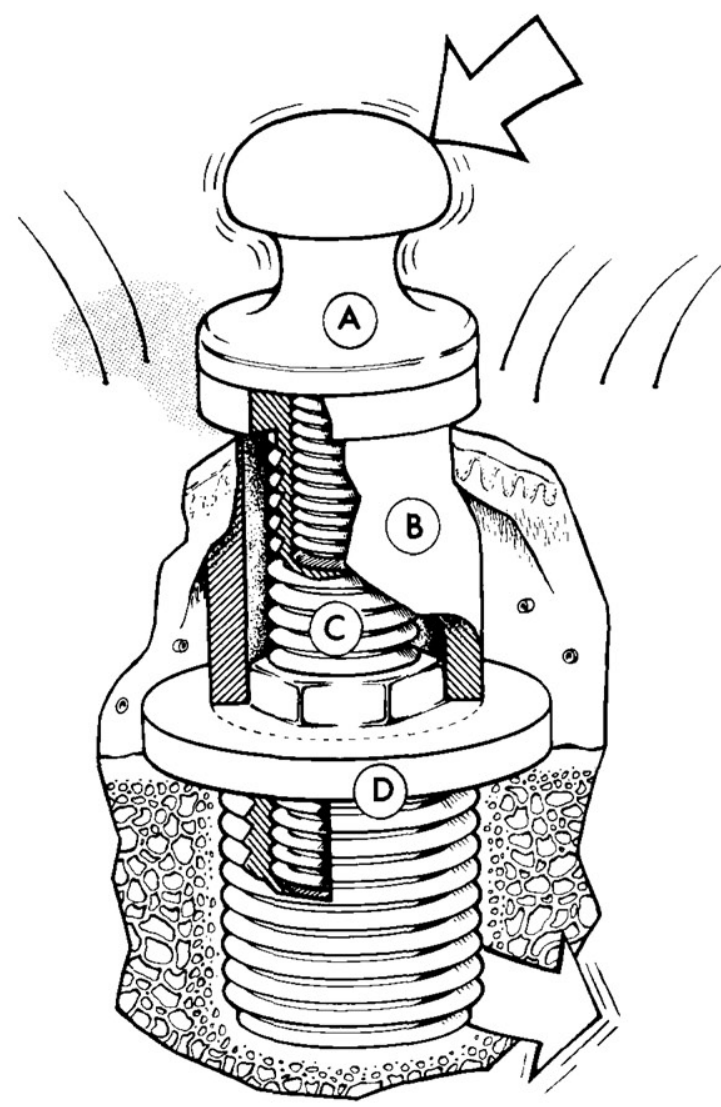

Fig. I. Osseointegrated titanium screw. (A) snap fastener; (B) titanium abutment; (C) connection screw; (D) titanium fixture.

as women who wish to have a more extreme hair style. Thus there is a need to develop a bone conduction hearing aid which minimizes these drawbacks. Our idea has been to use a bone-anchored fixture with a skin penetration to attach the hearing aid to. This arrangement could make it possible to construct a small and discrete hearing aid which would eliminate the need of pressure and also eliminate the damping effect of the soft tissue.

\section{Osseointegration}

The possibility of permanently implanting a foreign material in the body has previously been limited and a permanent, reaction-free skin penetration has been regarded as essentially impossible to realize. Experience from animal experiments (Brånemark \& Lindström, 1963; Brånemark \& Breine, 1964; Brånemark et al., 1969; Hallén et al., 1976) and corresponding clinical experiments (Brånemark et al., 1970; Brånemark et al., 1975; Brånemark et al., 1977; Tjellström et al., 1978a; Tjellström et al., 1978b) shows that titanium has unique properties both in its relation to bone tissue and to soft tissue.

Anchoring of a prosthetical tissue substitute according to the principle of osseointegration means that the surface of the implant connects directly to vital remodelling bone tissue without any intermediary connective tissue sheath. This bio-mechanical connection is obtained by using a combination of careful surgical technique based on biological knowledge about optimization of bone healing and by the use of an inert implant material. Nonalloyed titanium is preferred, the surface of which has a special microstructure with an architecture and dimension adjusted to the cellular and interstitial components of the bone tissue. The surface of the implant as well as the bone site are protected against all kinds of contamination. An osseointegrated implant can be supplied with extension elements for penetrating skin and mucous membrane, which will not be sites for inflammatory processes if the integration is preserved. Experience of these conditions have been collected for more than 10 years. During these years more than 1500 fixtures have been implanted in the oral cavity to be used for dental rehabilitation. In a pilot study of three patients and a follow up study of 11 more patients, titanium fixtures have been screwed into the bone of the linea temporalis of the temporal bone. All these patients used conventional bone conducting hearing aids previously and were not satisfied with them. After the titanium fixture had integrated with the bone for three to four months, a skin penetration was made using titanium abutments, held in place by titanium screws which also served as connections for the hearing aids, as shown in Fig. 1. The longest observation time is 26 months and the shortest six 


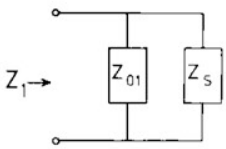

Fig. 2. Input impedance to the head $\left(Z_{1}\right)$ where $Z_{01}$ corresponds to the impedance of skin and subcutaneous tissue and $Z_{s}$ corresponds to the impedance of the skull.

months and no fixture has loosened from the bone (February, 1979). Depending on the immature technical design, a couple of the patients have complained about minor inconvenience from the fixtures. The hearing aids used by these patients have been of the same manufacture and the same type as their usual hearing aids.

The bone-anchored hearing aids operates with a changed input impedance looking into the head. The input impedance together with a given hearing aid with its associated electronics determines the input power to the head. The variation of the power with frequency is different for bone-anchored transmission and conventional skin and bone transmission. The patients used the same manufacture and type of hearing aids as before and most of them feel that the sound has a better quality for bone-anchored transmission than for conventional bone transmission. Optimization of the hearing aid should lead to a further increase in the sound quality. Such optimization requires a closer study of the impedance in the system. Psychoacoustic analysis must be carried out in order first to further develop the hearing aid and later to match the associated electronics.

The purpose of the study present here is to describe and investigate the mechanical system when an osseointegrated entrance to the skull is used. A comparison with the ISO/IEC standard for mechanical impedance in skinhead will also be carried out (Flottorp /Solberg, 1976).

Models_electrical analogs

Mechanical systems, of which sound transmission is one, are complicated and can best be described by models. These can be mechanical and can also be translated to electrical analogs. The mass corresponds to an inductance $(L)$, the elasticity to capacitance $(C)$ and damping to resistance $(R)$. The head with soft tissue and bone supported by soft tissue of the neck and neck bones can be considered a mechanical system. To study this system, two general models have been proposed. In one of the models, shown in Fig. 2, the impedance of the skin and subcutaneous tissue is discribed by $Z_{01}$. In the other model, shown in Fig. 3, the impedance of the snap fastener is described by $Z_{02}$ and $Z_{s}$ describes the impedance of the bone of the skull. The impedance of the osseointegrated titanium fixture is negligible because its mass is very small and the physical properties of titanium correspond well with those of bone. The construction of the snap fastener is shown schematically in Fig. 1. These two models describe the input impedance into the head in the frequency range 250 to $8000 \mathrm{~Hz}$, with and without skin penetration, respectively. If the mechanical snap fastener is stiffer than the skin including the subcutaneous tissue over the mastoid process, the snap fastener system, $Z_{1}$, is better than the system with subcutaneous tissue, $Z_{2}$.

\section{MEASUREMENT APPARATUS AND METHOD}

The measurements were made with Bruel \& Kjaer's impedance measurement apparatus, consisting mainly of an impedance head and a vibrator. A block diagram of the measurement apparatus is shown in Fig. 4. The impedance of the mass in the driving platform in the impedance head has been taken into account.

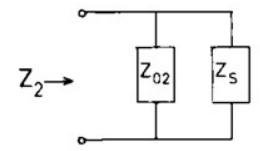

Fig. 3. Input impedance to the head $\left(Z_{2}\right)$ where $Z_{01}$ corresponds to the impedance of the snap fastener and $Z_{s}$ corresponds to the impedance of the skull. 


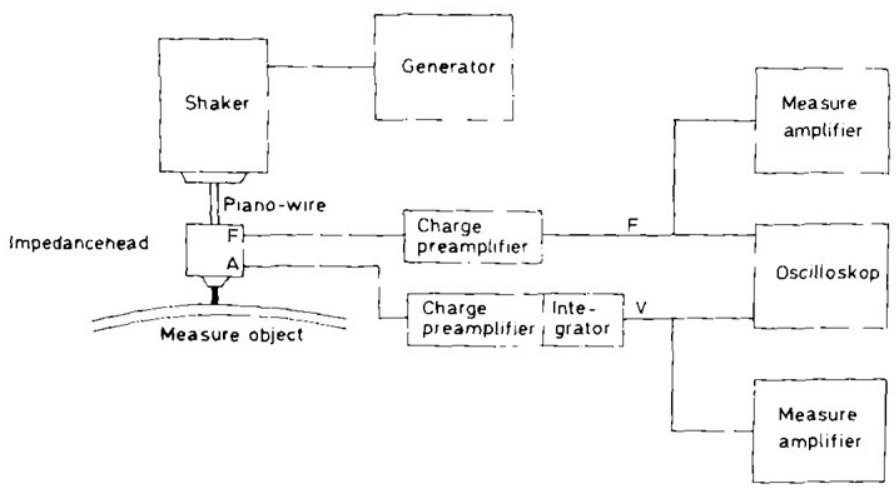

Fig. 4. Block diagram of the measurement apparatus.

The complex impedance, $Z$, is measured as magnitude (mechanical ohms) and phase (degrees). Calibration was performed with a known mass at $100 \mathrm{~Hz}$. The measurements were carried out with a vibration speed which was neither too low to detect nor too large to be unpleasant for the patients. The accuracy of the electrical measurements is estimated to be $\pm 5 \%$ for the magnitude and $\pm 2^{\circ}$ for the phase. Because the system is approximately linear (Flottorp \& Solberg, 1976), the impedance is insensitive to the applied signal strength.

Measurements have been carried out on eight patients, five women and three men. Their ages varied between 30 and 60 years. In order to simulate the attachment of the hearing aid to the snap fastener, the vibrator and im- pedance head were suspended from a wheel and balanced with a weight, as shown in Fig. 5. The patient lay horizontally and had a soft pillow under the head in order to avoid coupling to the supporting structures. To find out what parts of the impedance corresponded to the skull, $Z_{s}$, and to the snap fastener, $Z_{02}$, separate measurements were made on the snap fastener according to Fig. 6 . The female element was fastened to a large mass, $63 \mathrm{~kg}$, as shown in Fig. 6, in order to avoid coupling to the supporting structure.

The measurements were carried out at discrete frequencies between $250 \mathrm{~Hz}$ and 8000 $\mathrm{Hz}$. Measurements under $250 \mathrm{~Hz}$ are not considered because copuling to the supporting structures can affect the measurement result adversely.
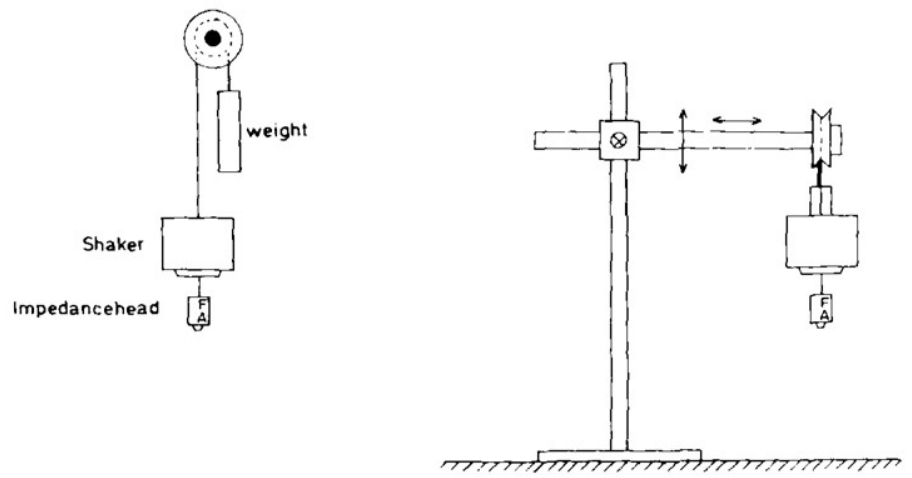

Fig. 5. Vibrator and impedance head mounted in a holder which is adjustable both vertically and horizontally.

Actu Otoluryingol 89 


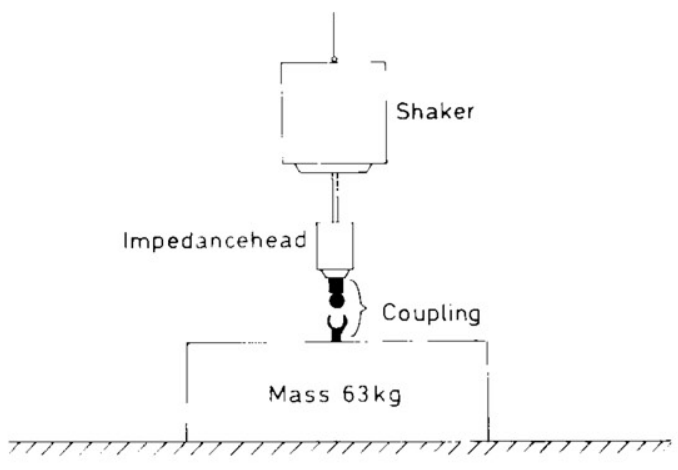

Fig. 6. Measurement apparatus for impedance measurements on snap fastener only.

\section{RESULTS}

The results of the magnitude (in mechanical ohms) and phase (in degrees) measurements are presented in Figs. 7 and 8. The curves show an average of the measurement results in eight patients. A scattering in the magnitude measurements of about $\pm 30 \%$ is noted for frequencies below $1250 \mathrm{~Hz}$ and over $5000 \mathrm{~Hz}$. Between these frequencies the scattering is less than $\pm 12 \%$. The bump at $1250 \mathrm{~Hz}$ is relatively flat in some cases. The curves obtanied for the various patients all had the same

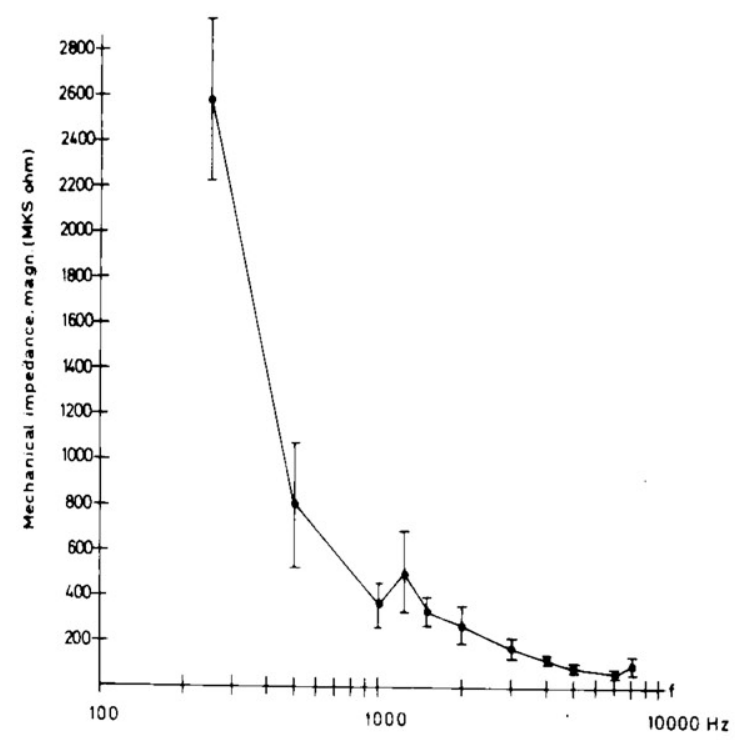

Fig. 7. Magnitude of the mechanical impedance (average). The scatter of the 8 patients is shown.

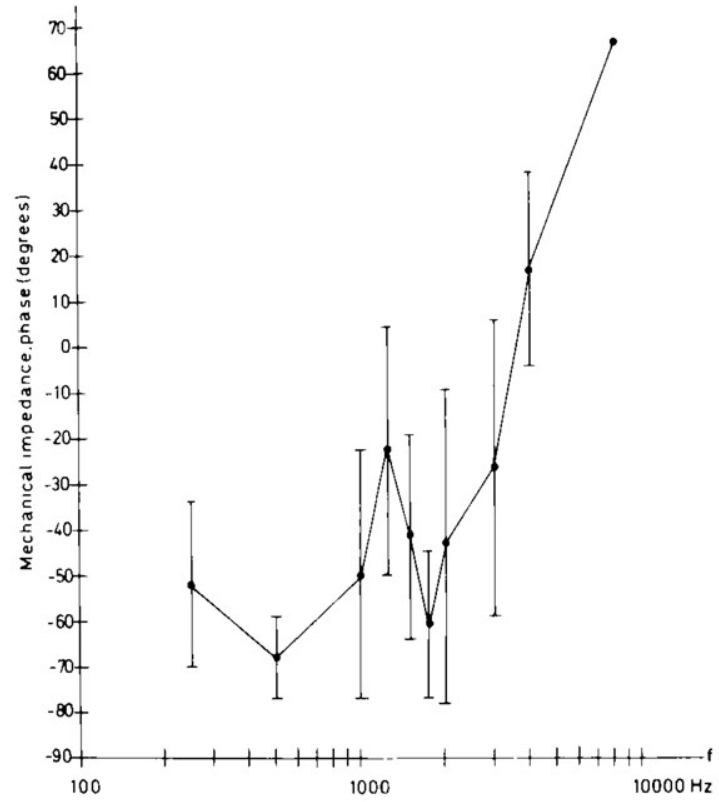

Fig. 8. Phase of the mechanical impedance (average). The scatter of the 8 patients is shown.

characteristics. From the magnitude and phase curves, the resistive and reactive impedance have been calculated and are shown in Fig. 9. The scattering of phase is larger than that of magnitude, which is caused by greater indi-

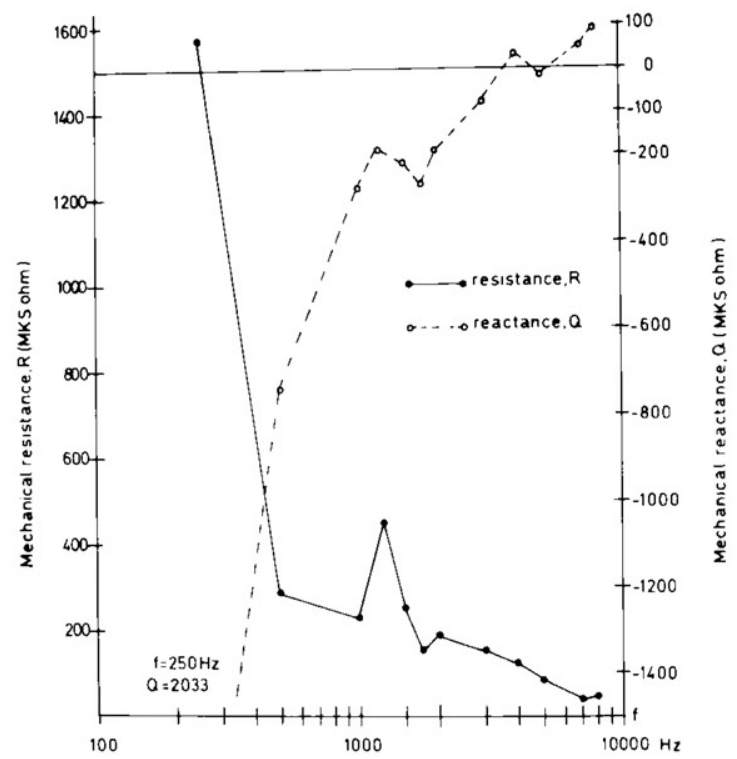

Fig. 9. Resistance and reactance of the mechanical impedance. 


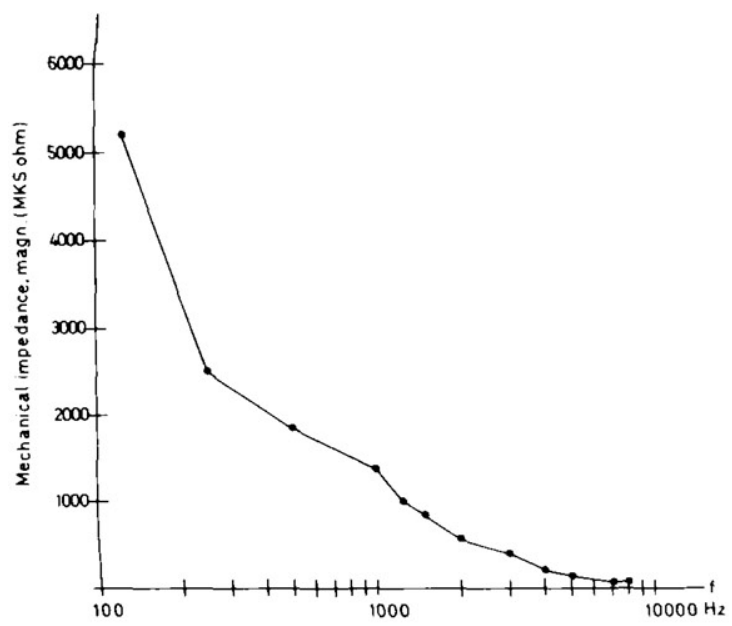

Fig. 10. Mechanical impedance of the snap fastener.

vidual variations and poorer precision in registering the results. The results of measurements on the snap fastener are shown in Fig. 10. A scattering caused by the tightness of the snap fastener (tight, medium, loose) was also noted. That scattering is about $\pm 15 \%$ for frequencies below $800 \mathrm{~Hz}$ and very small for higher frequencies.

\section{DISCUSSION}

The scattering in the measurement results is mainly explained by insufficient precision in the instruments, errors in reading the instruments and varying tightness in the snap fastener used. Variations in different skulls regarding elasticity and weight could also influence the scatter (Kylén, 1977).

The measurement results are discribed in an electrical analog model in which the block

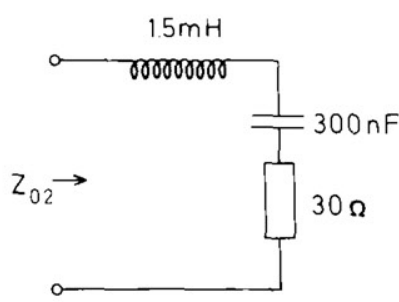

Fig. II. Electrical analog model of the snap fastener.

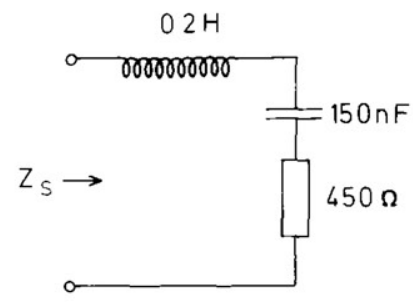

Fig. 12. Electrical analog model of the skull impedance for frequencies over $2 \mathrm{kHz}$.

elements in Figs. 2 and 3 are replaced by $R, C$ and $L$ combinations. The results of the measurements on the snap fastener give a model according to Fig. 11. The resonant frequency is then $7.5 \mathrm{kHz}$. This means that the inductance can be neglected for frequencies below $7.5 \mathrm{kHz}$. A comparison between the impedance of the snap fastener, $Z_{02}$, and that of the head shows that the impedance of the snap fastener determines the total impedence for frequencies over 2 to $3.5 \mathrm{kHz}$. This means that at higher frequencies, the impedance of the skull is considerably greater than than of the snap fastener.

For frequencies below 2 to $3.5 \mathrm{kHz}$ one finds that the total impedance, $Z_{2}$, has a resonant frequency at about $800 \mathrm{~Hz}$. According to Kirikae (1958) the skull has its lowest resonant frequency between 1.7 and $1.9 \mathrm{kHz}$. Kirikae's measurements were carried out on an unattached skull. The resonant frequency found in our measurements at about $800 \mathrm{~Hz}$ can be due to the attachment to the neck and spinal cord. An electrical analog of the impedance of the skull, $Z_{s}$, is shown in Fig. 12. This model is not valid for frequencies over 2

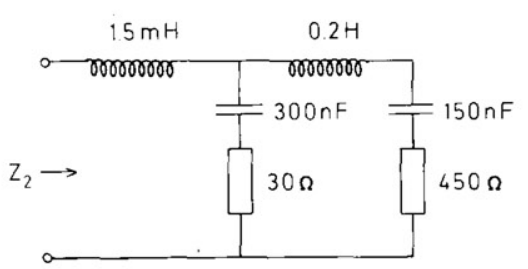

Fig. 13. Electrical analog model of the combined system snap fastener and skull. 


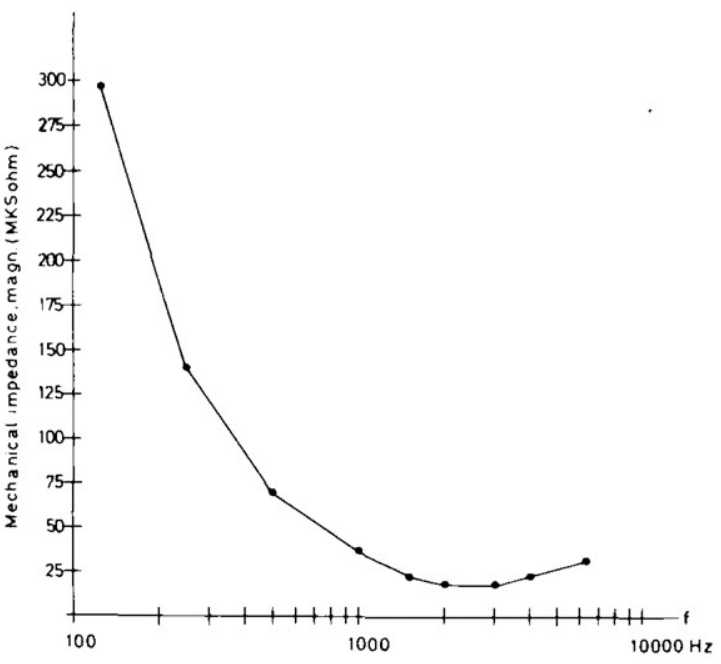

Fig. 14. Accepted ISO/IEC mechanical impedance, magnitude curve.

$\mathrm{kHz}$ because over that frequency the impedance of the snap fastener dominates and no information on the impedance of the skull is obtained.

According to Kirikae, the skull has several resonant frequencies at higher frequencies. A total electric analog model for the snap fastener and skull is presented in Fig. 13. An interesting observation is that the resonant frequency at $800 \mathrm{~Hz}$ coincides with the frequency

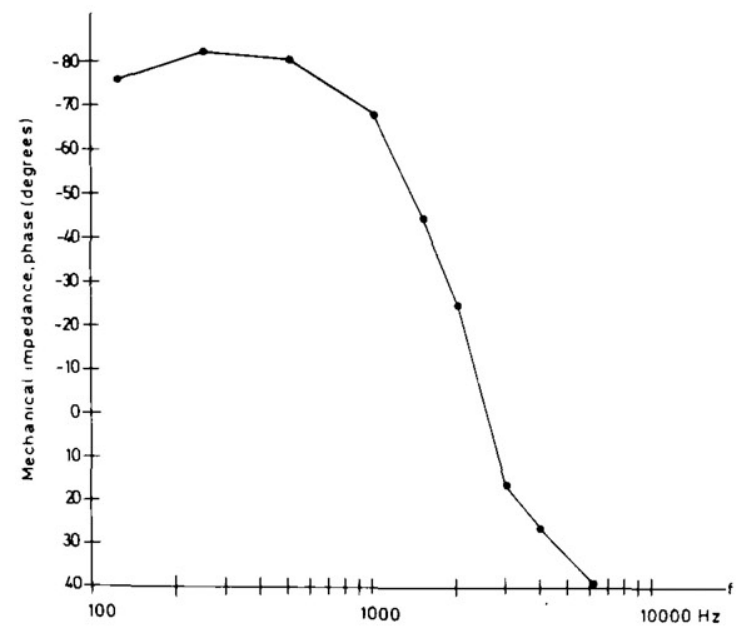

Fig. 15. Accepted ISO/IEC mechanical impedance, phase curve.

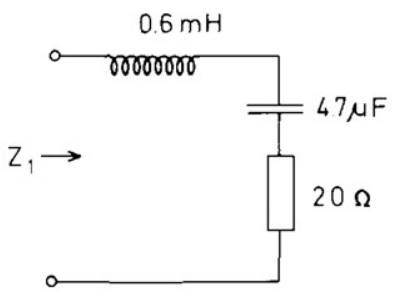

Fig. 16. Electrical analog model of the accepted ISO/IEC mechanical impedance.

region where bone transmission changes from osseotympanic to compression and depression in the temporal bone. The vibration pattern of the skull also changes in that frequency region (Kirikae, 1958), where also the resonant frequencies of the middle ear are found (Møller, 1974). The electrical analogs have been tested and evaluated with a computer analysis program, ANP (Analytic Network Program), and found to reproduce the measured impedance curves.

\section{Comparison with ISO/IEC standard impedance}

A comparison has been made between the measured impedances from this study and the ISO/IEC standard impedance. The impedance given in Fig. 2, $Z_{1}$, has the form given in Figs. 14 and 15 (Flottorp \& Solberg 1976). These curves have been produced in an electric analog model according to Fig. 16 (proposed ISO/IEC standard impedance). In comparison of $Z_{1}$ (without skin penetration) and $Z_{2}$ (with skin penetration), one finds that $Z_{2}$ is 20 to 25 $\mathrm{dB}$ larger than $Z_{1}$. This means that the impedance of the skull, $Z_{s}$, is considerably larger, $10-25 \mathrm{~dB}$, than the impedance of the skin and subcutaneous tissue $Z_{01}$. Then the ISO/IEC standard impedance is equal to the impedance of the skin and subcutaneous tissue of the head. The variation in $Z_{1}$ without skin penetration) in different age groups and between men and women, which has been discussed, probably derives from variations in skin and subcutaneous tissue (Flottorp \& Solberg, 1976). This observation agrees well with the experiments von Békésy performed in which 
he found that a large amount of sound energy is absorbed by the skin (Békésy, 1960). The same findings have been noted by Kylén (1977) in his amplitude analysis.

\section{Psychoacoustical aspects}

Some initial psychoacoustical measurements have been performed, but the results are still preliminary. The patients who have received bone-anchored hearing aids emphasize that the loudness increases greatly and that the volyme control on their apparaturs must be turned down to a minimum in order to get an agreeable sound level. They further emphasize that the frequency range is significantly increased in comparison with conventional bone transmission. These two factors mean that the quality of the sound reaching the cochlea can be improved. Much less power will be required to drive a hearing aid using an osseointegrated titanium fixture. At present the hearing aid fitting is being optimized for this new situation.

\section{ZUSAMMENFASSUNG}

Einige auf Hörgeräte angewiesene Patienten könne nicht einen Apparat, der den Schall durch den äußeren Gehörgang vermittelt, benützen, sondern müssen ein knochenleitendes Hörgerät anwenden. Das Gerät ist mit Hilfe eines Stahlbügels gegen die Haut des Processus mastoideus gedrückt, und der Schall ist durch die Weichteile und Knochengewebe zu der Schnecke verimittelt. Der Druck, der das Hörgerät verursacht, ist für den Patienten unangenehm. Die dämpfende Wirkung der Weichteile verringert die übermittelte Schallqualität. Die Möglichkeit, fremdes Material reaktionslos zu implantieren, um eine permanente Hautpenetration duchführen zu können, haben es ermöglicht, ein knochenverankertes Hörgerät herzustellen. Vierzehn Patienten sind mit solchen Apparten versehen. Wegen des neuen Verfahrens muß ein neues Gerät hergestellt werden. Die Impedanz der Knochenverankerten Titaniumschraube/Schädel wurde untersucht. Die Resistenz und Reaktanz der mechanischen Impedanz wurden gemessen. Die Einwirkung der dämpfenden Weichteile wurde analysiert. Der Unterschied zwischen der Impedanz des Schädels und die der Weichteile + Schädels betrung, abhängig von der Frequenz, etwa 10-25 dB.

\section{REFERENCES}

Békésy von, G. 1960. Experiments in hearing. McGrawHill, New York.

Brånemark, P.-I. \& Lindström, J. 1963. A modified rabbit's ear chamber. Anat Rec 145, 533.

Brånemark, P.-I. \& Breine, U. 1964. Formation of bone marrow in isolated segment of rib periosteum in rabbit and dog. Blut 10, 236.

Brånemark, P.-I., Breine, U., Adell, R., Hansson, B. O., Lindström, J. \& Ohlsson, A. 1969. Intra-osseous anchorage of dental prostheses. 1. Experimental studies. Scand J Plast Reconstr Surg 3, 81.

Brånemark, P.-I.. Lindström, J., Hallén, O., Breine, U. \& Hansson, B. 1970. Repair of defects in mandible. Scand J Plast Reconstr Surg 4. 100.

Brånemark, P.-I., Lindström, J., Hallén, O., Breine, U., Jeppson, P.-H. \& Öman, A. 1975. Reconstruction of the defective mandible. Scand J Plast Reconstr Surg 9. 116.

Brånemark, P.-I., Hansson, B. O., Adell, R., Breine, U., Lindström, J. \& Hallén, O. 1977. Osseointegrated implants in the treatment of the edentulous jaw. Almqvist \& Wiksell International, Stockholm.

Flottorp, G. \& Solberg, S. 1976. Mechanical impedance of human headbones (forehead and mastoid portion of the temporal bone) measured under ISO/IEC conditions. J Acoust Soc Am 59:4, 899.

Hallén, O., Brånemark, P.-I., Lindström, J. \& Tjellström, A. 1976. Preformed autologous ossicles. Experimental studies. Acta Otolaryngol (Stockh) 82, 394.

Kirikae, I. 1959. An experimental study on the fundamental mechanism of bone conduction. Acta Otolaryngol (Stockh), Suppl. 145.

Kylén, P. 1977. Drill-generated noise levels and peroperative temporary threshold shifts in ear surgery. Linköping University Medical Dissertations no. 45, Linköping.

Møller, A. R. 1974. The acoustic middle ear muscle reflex. In Handbook of sensory physiology. V/I. Auditory system. Springer-Verlag, Berlin.

Tjellström, A., Lindström, J., Albrektsson, T., Brånemark, P.-I. \& Hallén, O. 1978a. A clinical pilot study on preformed autologous ossicles. I. Acta Otolaryngol (Stockh) 85, 33.

Tjellström, A., Lindström, J., Albrektsson, T., Brånemark, P.-I. \& Hallén, O. 1978b. A clinical pilot study on preformed autologous ossicles. II. Acta Otolaryngol (Stockh) 85, 232.

A. Tjellström, M.D.

ENT-Dept. Sahlgren Hospital

University of Göteborg

S-41345 Göteborg

Sweden 